\title{
Stratigraphy and structure of the Punta Negra Anticline. Implications on the structural evolution of the Argentine Precordillera
}

\author{
J. L. Alonso ${ }^{1 *}$, J. Gallastegui ${ }^{1}$, L. R. Rodríguez Fernández ${ }^{2}$, J. García-Sansegundo ${ }^{1}$ \\ ${ }^{1}$ Departamento de Geología, Universidad de Oviedo, C/ Jesús Arias de Velasco s/n, 33005 Oviedo, Spain \\ ${ }_{2}^{2}$ Instituto Geológico y Minero de España, C/ La Calera 1, 28740 Tres Cantos, Madrid, Spain. \\ e-mail addresses: jlalonso@geol.uniovi.es (J.L.A.; *corresponding author); jorge@geol.uniovi.es (J.G.); j.g.sansegundo@geol.uniovi.es (J.G.-S.), \\ lr.rodriguez@igme.es (L.R.R.F.)
}

Received: 17 July 2013 / Accepted: 5 May 2014 / Available online: 25 June 2014

\begin{abstract}
The Punta Negra Anticline is a thrust-related fold, several kilometres wide, located at the front of the Argentine Central Precordillera. A stratigraphic succession including Ordovician, Silurian and Devonian rocks is exposed in its core, instead of a Devonian and Carboniferous succession as previously had been considered. The Punta Negra Anticline also involves a Tertiary sequence displaying syntectonic unconformities in the transition between the Albarracín and Mogna formations, recording the timing of thrusting and folding at the front of the Central Precordillera. This anticline folds thrust systems detached at the Silurian and Devonian shales, which we interpret as pre-Andean (Gondwanan) thrusts in this part of the Precordillera. The pre-Andean age of these thrusts is also consistent with their truncation by Tertiary subvolcanic intrusive bodies that predate the onset of the Andean deformation in the Punta Negra area. Moreover, the size and structural style of the Punta Negra Anticline, Andean in age, is in contrast with the other folds of the Central Precordillera, whose sizes do not exceed the hectometric scale and can be related to Gondwanan thrusting. This implies an Andean deeper thrust, probably detached at the bottom of the Cambrian succession.
\end{abstract}

Keywords: Argentine Precordillera, Palaeozoic stratigraphy, Gondwanan structure, Andean structure, syntectonic unconformities

Resumen

El Anticlinal de Punta Negra es un pliegue de varios kilómetros de anchura, relacionado con el cabalgamiento frontal de la Precordillera Central Argentina. Previamente se había considerado que las rocas más antiguas expuestas en dicho anticlinal eran devónicas, pero la sucesión estratigráfica que aflora en su charnela incluye también rocas ordovícicas y silúricas. El Anticlinal de Punta Negra también involucra una sucesión de edad terciaria, la cual muestra discordancias sintectónicas en el tránsito entre las formaciones Albarracín y Mogna, proporcionando información sobre la edad y evolución de dicha estructura. El anticlinal pliega cabalgamientos despegados en las pizarras silúricas y devónicas, que interpretamos como de edad pre-Andina (Gondwánicos). Estos cabalgamientos están cortados por cuerpos intrusivos subvolcánicos que son anteriores a la edad propuesta para el comienzo de la deformación Andina en el área de Punta Negra. Además, el tamaño y estilo del Anticlinal de Punta Negra, de edad Andina, contrastan con el resto de los pliegues de la Precordillera Central, cuyos tamaños no exceden de centenares de metros y pueden ser atribuidos a la deformación Gondwánica. Ello implica un cabalgamiento mas profundo en el Anticlinal de Punta Negra, probablemente enraizado en la base de la sucesión cámbrica.

Palabras clave: Precordillera Argentina, estratigrafía del Paleozoico, estructura gondwánica, estructura andina, discordancias sintectónicas

\section{Introduction}

The Argentine Precordillera is a fold-and-thrust belt, about $80 \mathrm{~km}$ wide, which involves Palaeozoic rocks and Tertiary sediments (Bracaccini, 1946-1950; Heim, 1952). The Precordillera has classically been divided into Western, Central and Eastern domains based on stratigraphic and structural features (Ortiz and Zambrano, 1981) (Fig. 1). The Central and Eastern Precordillera represent a stable carbonate platform during Cambrian to Early Ordovician times (Bordonaro, 1999). The Western Precordillera is characterized by olistostrome or melange deposits, related to extensional tec- 
tonics during Ordovician times, in a continent-ocean transition (von Gosen, 1992; Astini, 1997; Keller, 1999; Alonso et al., 2008a) and ocean floor sediments with pillow basalts in the westernmost part (Kay et al., 1984; González-Menéndez et al., 2013). This continental margin remained stable until Late Devonian. Early Carboniferous deposits known as the El Ratón Formation (Azcuy et al., 1981) and Jejenes Formation (Amos, 1954) overlie older Palaeozoic rocks along a strong angular unconformity.

Regarding the structure, the Central and Western Precordillera form an east-verging imbricate thrust system, while the Eastern Precordillera consists of west-verging structures (Baldis and Chebli, 1969; Allmendinger et al., 1990; von Gosen, 1992; Ramos, 1995). Triassic and Tertiary rocks lie with angular unconformities on Palaeozoic rocks but are also involved in the thrusting and folding in the Precordillera. Most of the Andean structures have been considered as the reactivation of older ones developed during Carboniferous to Permian times (Alonso et al., 2005). The Andean deformation age is considered to be Miocene to Recent, with west to east progression of thrusting (Jordan et al., 1993; Zapata and Allmendinger, 1996b; Ramos, 1999).

This paper presents new data on the stratigraphy and structure of the Punta Negra Anticline, the most frontal structure of the Argentine Central Precordillera (Fig. 1). An Ordovician to Silurian succession is documented for the first time in the study area and compared with other sections of the Central Precordillera. On the other hand, the superposed structures located in the anticlinal core allow us to identify Andean and pre-Andean structures. Moreover, the syntectonic uncon- formities developed in the upper part of the stratigraphic succession record the timing of the anticline growth.

\section{Stratigraphy}

The stratigraphy of the study area is summarized in the explanation of figure 2, which shows the geological map of the Punta Negra Anticline in the Río San Juan sector. Up to now, the Punta Negra Anticline has been interpreted as a simple anticline involving Devonian, Carboniferous and TertiaryQuaternary sediments (Heim, 1952; Baldis and Chebli, 1969; von Gosen, 1992; Ramos and Vujovich, 2000). During the present study we have identified an Ordovician to Silurian succession outcropping in the anticlinal core; this succession was probably not recognized previously due to many subvolcanic intrusive bodies of Tertiary age (Leveratto, 1968), which mask and obliterate the stratigraphy in that core (Fig. 2). However, in spite of the discontinuous exposures of the sedimentary units, a consistent reconstruction of both, stratigraphy and structure has been carried out in between the intrusive bodies (Figs. 2 and 3).

The oldest formation exposed in the Punta Negra Anticline is the Lower Ordovician San Juan Limestone. Overlying the San Juan Formation there is a sequence of fine-grained sandstones (Fig. 4A), shales and siltstones containing a Silurian fauna of Atripina sp. in its upper part (classified by L. Benedetto, personal communication, 2007). Most of this sequence can be correlated with the Los Espejos Formation, first established by Cuerda (1969), but a few meters of sandstones with chert levels occurring in the lowermost part, probably belong
Fig. 1.- Location and geological domains of the Argentine Precordillera showing the location of figure 2 and the trace of the cross-section of figure 8 .

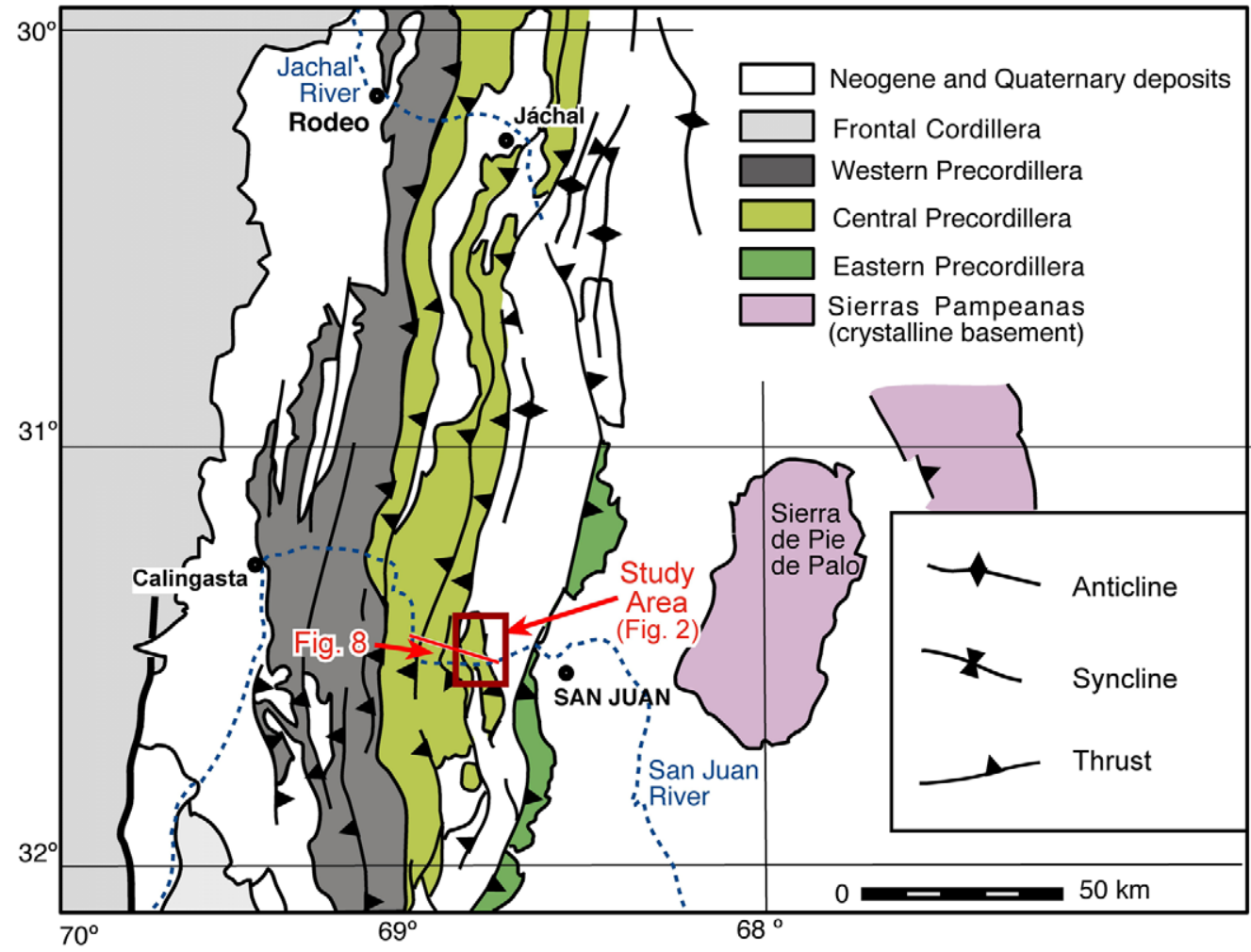



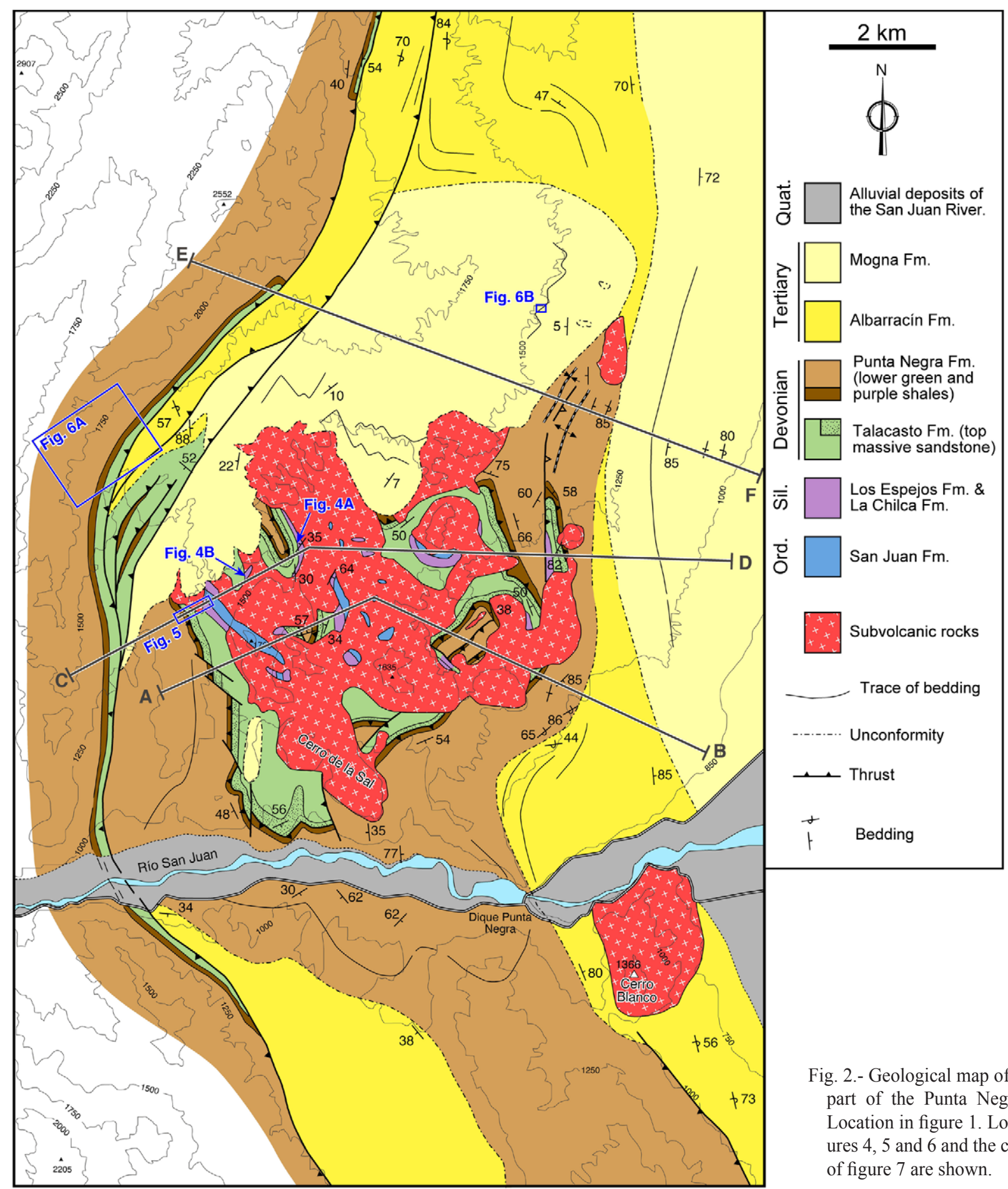

to the La Chilca Formation. The Palaeozoic succession of the Punta Negra Anticline should display a stratigraphic gap of Upper Ordovician age, as in other parts of the Central Precordillera (Bracaccini, 1949), interpreted as evidence for a peripheral bulge produced in a foreland basin as the result of the collision of the Cuyania terrane with the Gondwana margin (Astini et al., 1996; Astini, 2003; Ramos, 2004). Near the top of the Silurian succession there is a level displaying extensional microfractures developed in not well-lithified sandstones; some slump folds also occur in adjacent shales and siltstones (Fig. 4B). We have recognized the same level, containing gravity-driven structures, in the classical Talacasto section.

The Devonian succession comprises two stratigraphic units. The lower unit (Talacasto Formation) consists of a basal member of massive green shales with limestone nodules. This succession underlies a thickening-upward sequence composed of intercalated shales and sandstones, which terminates with a well-sorted and massive sandstone at the top, thicker than $10 \mathrm{~m}$. Previously, this stratigraphic unit had been 


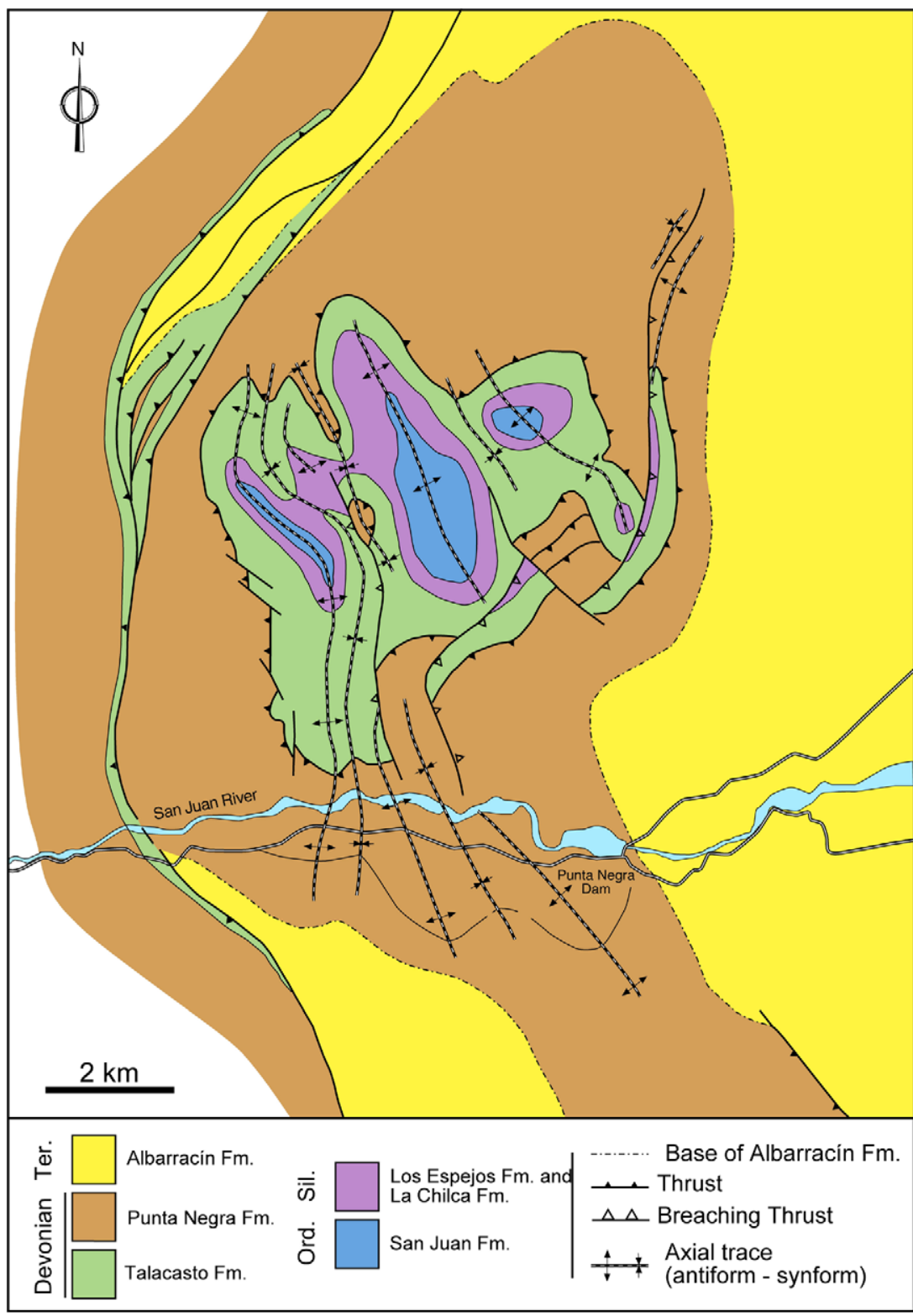

Fig. 3.- Structural reconstruction and interpretation of the Punta Negra Anticlinorium avoiding the subvolcanic bodies and showing the main faults and folds. mation) begins with purple and green shales which grade upwards into a graywacke-shale sequence (Astini, 1991). A panoramic view of the Silurian to Devonian succession in the western limb of the anticline is shown in figure 5.

The Tertiary-Quaternary succession represents the infill of the Andean foreland basin (Ramos, 1999). It unconformably overlies the Palaeozoic succession (Alonso et al., 2005), with a slight palaeorelief at the unconformity surface (Vergés et al., 2001). It is a coarseningand thickening-upward succession deposited in fluvial and alluvial systems and its lowermost part is lower Miocene in age (Milana, 1991; Vergés et al., 2001; Milana et al., 2003). The Neogene sequence comprises two formations. The oldest is the Albarracín Formation (Leveratto, 1968), up to $1400 \mathrm{~m}$ thick, with an age ranging between 18 and $7 \mathrm{Ma}$ in the western limb of the Punta Negra Anticline (Vergés et $a l ., 2001)$. This formation is composed of finegrained terrigenous redbeds with interfingered pyroclastic rocks in the middle (Bercowski and Figueroa, 1987) and conglomeratic beds in the upper part (Fig. 6A). The Mogna Formation (Kelly, 1962) overlies the Albarracín Formation in the eastern limb of the Punta Negra Anticline (Fig. 2). This uppermost unit is more than $2000 \mathrm{~m}$ thick and consists of massive conglomerates and breccias (Fig. 6B). The boundary with the Albarracín Formation is transitional, although as a result of its syntectonic deposition, the Mogna Formation also lies with an angular unconformity over the Albarracín Formation in the upper part of the fold limbs and on the Devonian succession in the anticlinal crest zone (Fig. 2). assigned to the Carboniferous in geological maps and crosssections (Heim, 1952; Ramos and Vujovich, 2000; Alonso et al., 2008b) and correlated with the La Deheza Formation defined by Cuerda and Furque (1983) in the headwaters of the La Deheza creek. However, the palynological analysis of a sample collected in the massive shales indicates that a Carboniferous age should be discarded for the basal member (S. Césari, personal communication, 2012). Moreover, the stratigraphic order and facies of that succession are very similar to those that occur in the Talacasto section, where the thickest sandstone level attains to $90 \mathrm{~m}$. Nevertheless, the Talacasto Formation is thinner (up to 200m) in the Punta Negra Anticline than in the Talacasto section $(600 \mathrm{~m})$. This is in agreement with the southwards decrease in thickness of the Silurian-Devonian units described by Baldis and Peralta (1999). The upper unit of the Devonian succession (Punta Negra For-

\section{Structure of the Punta Negra Anticline}

Since the pioneer works of Bracaccini (1950) and Heim (1952), the Punta Negra Anticline has traditionally been considered a simple fold with a reverse fault in its eastern limb, the reverse fault being interpreted as the frontal thrust of the Central Precordillera. Later, the Punta Negra Anticline has been interpreted as a fault-bend fold detached in the Silurian shales (Gardini, 1993; Cristallini and Ramos, 2000). A different interpretation linking the Punta Negra Anticline to a west verging thrust was proposed by von Gosen (1992). On the other hand, Alonso et al. (2008b) documented a more complex structure in the anticlinal core than previously assumed. The geometry of this structure is masked and obliterated by many dacitic and andesitic subvolcanic bodies and pyroclastic flows (Leveratto, 1968), their ages ranging from 18 to 7 

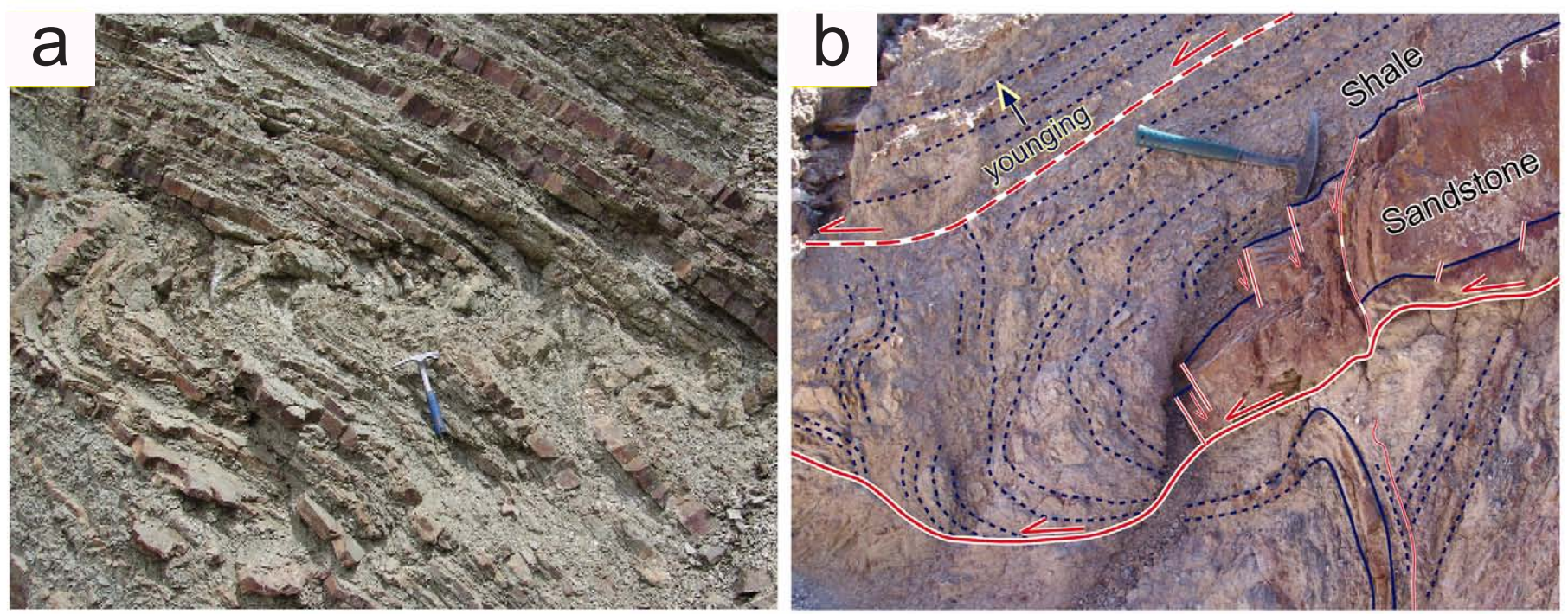

Fig. 4.- (a) Sandstone and shale alternations of the Los Espejos Formation. (b) Extensional faults of hydroplastic type at the roof of a sandstone bed and slump folds in the surrounding shales. Upper part of the Los Espejos Formation. Location in figure 2.

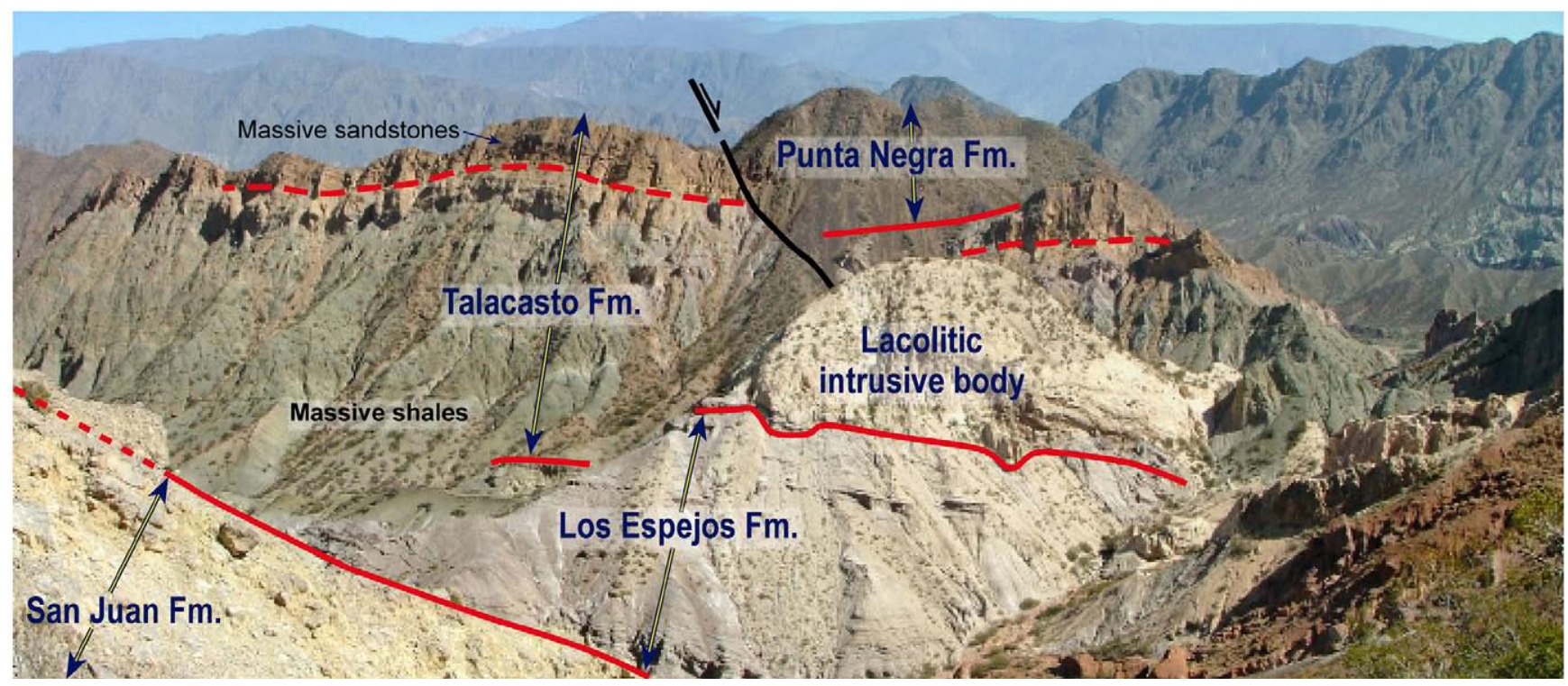

Fig. 5.- Panoramic view of the Palaeozoic succession in the western limb of the Punta Negra Anticline. Location in figure 2.
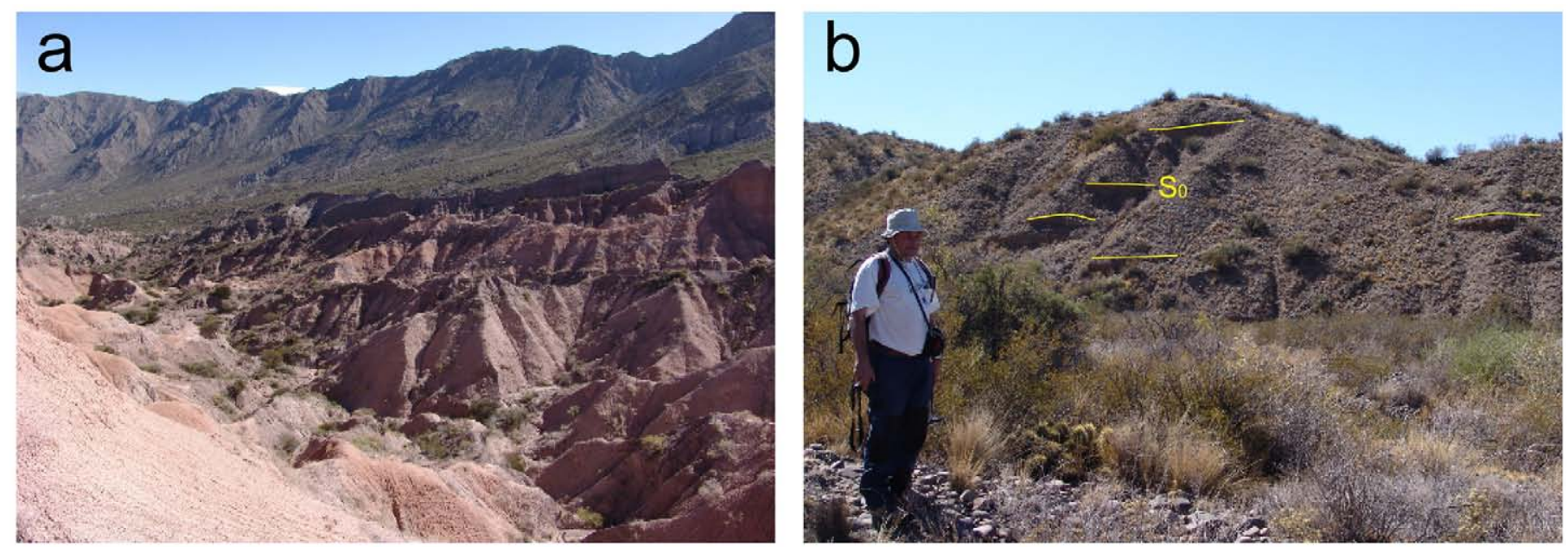

Fig. 6.- (a) Panoramic view of the Albarracín Formation in the western limb of the Punta Negra Anticline. The darker beds give rise to steeper scarpments are conglomeratic beds. (b) The conglomerates and breccias of the Mogna Formation in the crest of the Punta Negra Anticline. Location in figure 2. 
E
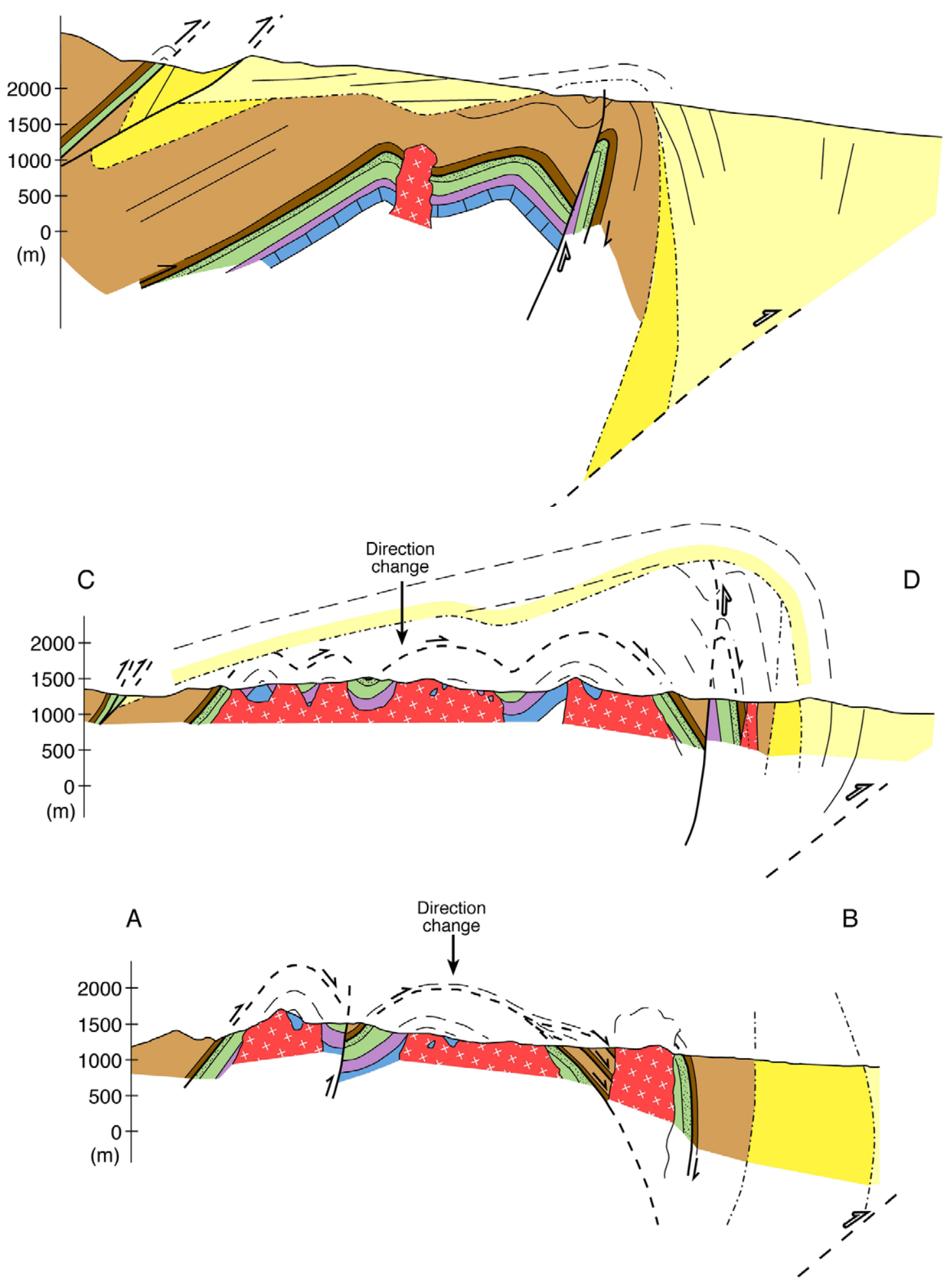

Fig. 7.- Geological sections across the Punta Negra Anticlinorium. Location and legend in figure 2.

Ma (Leveratto, 1976; Bercowski et al., 1986, 1993; Vergés et al., 2001).

The cross-sections shown in figure 7, the general cross-section of figure 8 and the structural map of figure 3 illustrate the geometry of the Punta Negra Anticline. At the southern border of the study area, the Punta Negra Anticline is a rounded, east-verging asymmetric fold with a horizontal axis, involving both, Palaeozoic and Tertiary beds. The Tertiary beds dip up to $40^{\circ}$ in the backlimb, whereas in the forelimb they are overturned as much as $55^{\circ}$. Where overturning is important, a thrust with omission of the lower part of the Albarracín Formation follows the contact with the Punta Negra Formation 
(Figs. 2 and 3). To the north of San Juan River it is a wider anticlinorium, composed of several smaller folds whose detailed geometry is shown in figure 7 . There are three major NNW trending anticlines, with domical geometries in the eastern part of the anticlinorium, and the correspondent synclines in the midst between them (Fig. 3). Moreover, regarding the internal structure of the anticlinorium, there are also faults duplicating the Silurian-Devonian succession. These faults are rooted in two different décollement levels. The upper décollement is located in the lower shales of the Punta Negra Formation and repeats that formation three times in the southeastern part of the anticlinorium core (Fig. 2 and cross-section A-B in Fig. 7). The lower décollement is situated at the base of the Silurian succession, duplicating the Los Espejos and Punta Negra formations to the east of the abovementioned thrusts (Fig. 2, cross-sections C-D and E-F in Fig. 7). Its displacement is accommodated by folds in the northern tip of the fault (Fig. 3 and cross-section E-F in Fig. 7). Taking into account the usual east-directed tectonic transport in the Central Precordillera, this fault can be interpreted as a back-thrust, which rotated up to a subvertical attitude in the eastern limb of the Punta Negra Anticlinorium.

All the abovementioned faults can be considered as preAndean thrusts because they are truncated by subvolcanic intrusive bodies, dated $16 \mathrm{Ma}$ at the Cerro de la Sal (Fig. 2) (Leveratto, 1976). This age indicates that these thrusts should be older than $16 \mathrm{Ma}$ in contrast with the age of $5 \mathrm{Ma}$ proposed by Zapata and Allmendinger (1996b) for the onset of the Andean deformation at the front of the Central Precordillera. The volcanic activity in the Punta Negra and Ullum areas has been documented from $18 \mathrm{Ma}$ (pyroclastic flows in the Albarracín Basin) up to $7 \mathrm{Ma}$ (Cerro Blanco intrusive) and is coetaneous with the deposition of the Albarracín Formation (Bercowski and Figueroa, 1987; Vergés et al., 2001; Bracco et al., 2011). Other arguments supporting a pre-Andean age for the abovementioned faults are the thickness changes of the Devonian succession in different sectors of the Punta Negra Anticlinorium. The minimum thickness of the Devonian succession occurs in the easternmost area of the anticlinorium, just in the hangingwall of the west-directed back-thrust (Fig. 2 and A-B section in Fig. 7). A greater thickness, preserved in the footwall, can be explained as a result of preMiocene denudation of the hangingwall, giving rise to the unconformable relationship between the Albarracín Formation and the Palaeozoic succession. However, this unconformity angle around the Punta Negra Anticline ranges only from $0^{\circ}$ to $10^{\circ}$ and is in contrast with the sector to the west, where the Palaeozoic beds usually dip $20^{\circ}-30^{\circ}$ more steeply than the Tertiary strata (Alonso et al., 2005) (Fig. 8). Regarding the significance of this angular unconformity, there are two possible interpretations. It could be originated by an early Andean (pre-Miocene) thrusting or the result of an older preAndean deformation. If there was an early Tertiary thrusting in the Central Precordillera, we should expect an important paleorelief, coarse clastics and diachronism in the base of the
Neogene sequence, as occurs in the so-called wedge-top basins. However, the basal part of the Miocene basin in the Precordillera displays features of a typical foreland basin located ahead of the deformation front, representing the response to the emplacement of the Cordillera Frontal to the west (Ramos, 1999). Therefore, we have suggested that pre-Miocene thrusting in the Central Precordillera may be of Gondwanan age (Alonso et al., 2005), because no stratigraphic record of previous Tertiary deformations has been found in this part of the Andes. It can be attributed to the Early Permian Sanrafaelic deformation phase (Ramos, 1988) identified in the Mendoza area to the south of the Precordillera.

\section{Age and significance of the Punta Negra Anticline}

As a whole, the Punta Negra Anticlinorium displays a western limb dipping $\sim 50^{\circ}$ to the west and a subvertical eastern limb that may be slightly overturned (up to $80^{\circ}$ when we move away from the anticlinal crest). The Punta Negra Anticline and the Matagusanos Syncline located in front of it in the east, can be interpreted as a typical fault-propagation fold pair related to a thrust located in their shared limb (Fig. 8). Both folds involve Neogene formations; therefore they are Andean in age.

The size of the Punta Negra Anticline, several kilometres wide, and its structural style differ from the other folds of the Central and Western Precordillera, whose sizes do not exceed the hectometric scale and can be related to Gondwanan thrusting (Fig. 8). The imbricate thrust of the Central Precordillera (Fig. 8) is detached at the Ordovician carbonates and cuts up the stratigraphic section eastwards (von Gosen, 1992), but the size of the Punta Negra Anticline implies a deeper thrust, probably detached at the base of the Cambrian succession (Fig. 10) (Alonso et al., 2005). This model is consistent with the thickness of the Cambrian succession, close to $3,000 \mathrm{~m}$, and the geological map, because Cambrian carbonates are exposed further to the north in the frontmost part of the Central Precordillera (Sierras of Talascasto, Cumillango, La Silla-Potrerillos, Guandacol) (Bordonaro, 2003). Wide anticlines at the level of Cambrian-Ordovician carbonates are present in these ranges, in contrast to the smaller hangingwall ramp anticlines developed in the Ordovician limestones of the Central Precordillera (Fig. 8). The inferred displacement (about $10 \mathrm{~km}$ ) and the depth of décollement of the Punta $\mathrm{Ne}$ gra structure in figure 8 is close to the values obtained for the frontal thrust by Zapata and Allmendinger (1996a) in the Rio Jachal section, $100 \mathrm{~km}$ to the north.

The geological map in figure 2 and the cross-sections shown in figure 7 illustrate the geometric relationships between the different stratigraphic units involved in the Punta Negra Anticline that record the precise age of the anticlinal growth. The Albarracín Formation is a pregrowth unit (Vergés et al., 2001), but the basal contact of the Mogna formation displays a typical syntectonic unconformity. To the north of the San Juan River, the Mogna Formation lies with strong angular un- 


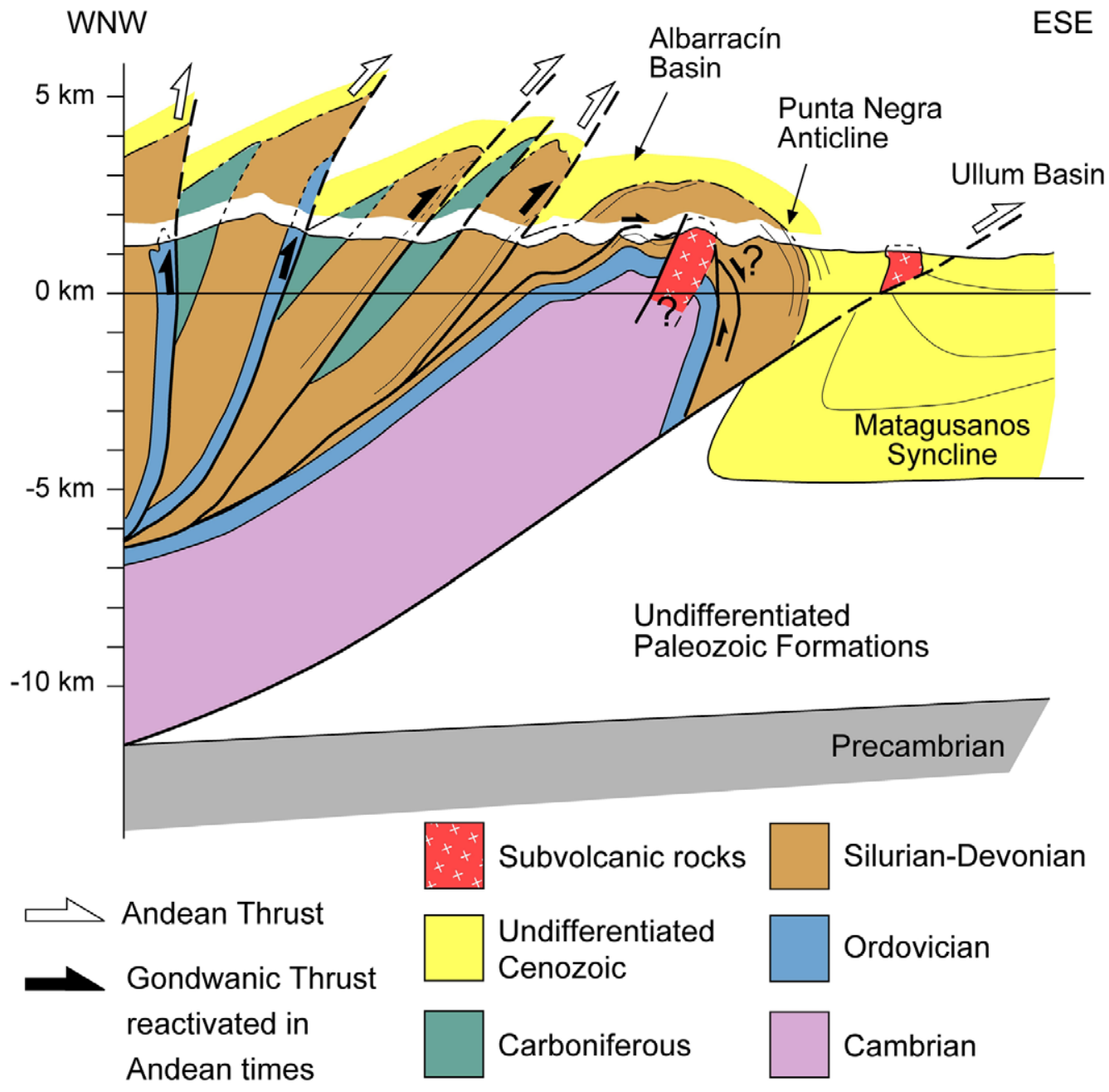

Fig. 8.- Cross-section of the eastern part of the Argentine Central Precordillera along the San Juan River (modified form Alonso et al., 2005). Location in figure 1.

conformity and palaeorelief on Palaeozoic beds on the crest of the Punta Negra Anticline (Figs. 2 and 7), as a result of crestal denudation, and lies on the Albarracín Formation on both limbs of the anticline. Although we have not observed the dip variation called progressive unconformity (Riba, 1976) on fold limbs, which is a common feature of many growth folds, the Albarracín Formation displays a wedge shape, increasing its thickness when we move away from the top of the anticline (Figs. 2 and 7). It implies that the Punta Negra Anticline began to grow before the beginning of the Mogna deposition, probably at $\sim 5$ or $6 \mathrm{Ma}$, taking into account the diacronism of the basal contact of the Mogna Formation, prograding eastward, because the base of this formation has an age of $4 \mathrm{Ma}$ at Mogna, located $10 \mathrm{~km}$ away to the east in the eastern Precordillera (Milana et al., 2003). Moreover, the unconformable Mogna Formation is also folded by the anticline (Fig. 7); so both limbs also rotated after the deposition of the upper member of that formation. In fact, the widespread Quaternary deformation and recorded seismicity in the Eastern and Central Precordillera imply that deformation is still active (Vergés et al., 2007).

\section{Conclusions}

To the north of San Juan River, the Punta Negra Anticline changes to a wide anticlinorium, involving a Palaeozoic succession composed of Ordovician, Silurian and Devonian formations, instead of a Devonian to Carboniferous succession as had previously been considered.

The structure of this anticlinorium is the result of the superposition of Andean and probably pre-Andean deformations. In its core, there are thrusts duplicating the Silurian-Devonian succession, which are truncated by subvolcanic intrusive bodies that predate the onset of the Andean deformation. These thrusts can be attributed to the Gondwanan deformation.

As a whole, the Punta Negra Anticlinorium is an eastverging asymmetric tight fold that can be interpreted as a fault-propagation fold, related to the thrust located in its forelimb. This fold involves Cenozoic formations displaying a syntectonic unconformity. It records that the anticline began to grow during the deposition of the uppermost part of the Albarracín Formation, but it was mostly amplified during the last stages of deposition of the Mogna Formation. 
The Punta Negra Anticline is several kilometres wide and this size implies a deep detachment, probably at the bottom of the Cambrian succession. It implies the development of a décollement deeper than the usual detachment of the thrust system in the Central Precordillera, which is located in the Lower Ordovician limestones and cuts-up the stratigraphic section eastwards.

\section{Acknowledgements}

We thank Victor Alberto Ramos who suggested us working in the Punta Negra structure and alerted us on the ocurrence of limestones between the intrusive bodies. We are also grateful to Oscar Limarino and Silvia Césari for accurate corrections on a previous version of this paper. Reviews by W. Von Gosen, V. A. Ramos and an anonymous rewiever have improved the manuscript. This work was supported by Spanish MICIN research projects BTE2002-04316-C03-03, CGL2006-12415-C03-02, CGL2012-34475 and the Consolider-Ingenio 2010 Programme, project CSD2006-0041, "Topo-Iberia" and FEDER Funds of the EU.

\section{References}

Allmendinger, R.W., Figueroa, D., Snyder, D., Beer, J., Mpodozis, C. and Isacks, B.L. (1990): Foreland shortening and crustal balancing in the Andes at 308S latitude. Tectonics 9, 789-809. doi:10.1029/ TC009i004p00789

Alonso, J.L., Rodríguez Fernández, L.R., García-Sansegundo, J., Heredia, N., Farias, P. and Gallastegui, J. (2005): Gondwanic and Andean structure in the Argentine Central Precordillera: the Río San Juan section revisited. 6th International Symposium on Andean Geodynamics. IRD Editions (Institut de Recherche pour le Développement), Extended Abstracts,Paris, pp.36-39

Alonso, J.L., Gallastegui, J., García-Sansegundo, J., Farias, P., Rodríguez Fernández and Ramos, V. A. (2008a): Extensional tectonics and gravitational collapse in an Ordovician passive margin: The Western Argentine Precordillera. Gondwana Research 13, 204-215. doi:10.1016/j.gr.2007.05.014

Alonso, J.L., Gallastegui, J., García-Sansegundo, J., Farias, P., Rodríguez Fernández, L.R., Heredia, N. and Ramos, V. A. (2008b): La Ventana Tectónica de Ullum: nueva interpretación estructural (Precordillera de San Juan). XVII Congreso Geológico Argentino, Jujuy, Actas 1, pp. 61-62.

Amos, A.J. (1954): Estructura de las formaciones paleozoicas de $\mathrm{La}$ Rinconada, pie oriental de la sierra Chica de Zonda, San Juan. Revista de la Asociación Geológica Argentina 9, 5-38.

Astini, A.R. (1991): Sedimentología de la Formación Talacasto: Plataforma fangosa del Devónico Precordillerano, Provincia de San Juan. Revista de la Asociación Geológica Argentina 44, 277-294.

Astini, R.A. (1997): Las unidades calcáreas del Ordovícico Medio y Superior de la Precordillera Argentina como indicadores de una etapa extensional. II Jornadas de Geología de Precordillera, San Juan, Argentina, Actas, pp. 8-14.

Astini, R.A., (2003): The Ordovician Proto-Andean Basins. In: Benedetto, J.L. (ed.) Ordovician Fossils of Argentina, Secretaría de Ciencia y Tecnología, Universidad Nacional de Córdoba, 1-74.

Astini, R., Ramos, V.A., Benedetto J.L. and Vaccari, N.E. (1996): La Precordillera: un terreno exótico a Gondwana. XIII Congreso Geológico Argentino y III Congreso Exploración de Hidrocarburos, Buenos
Aires, Actas V, 293-324.

Azcuy, C.L., Cesari, S.N. and Longobucco, M.I. (1981): Las plantas fósiles de la Formación El Ratón (Provincia de San Juan). Ameghiniana $18,11-28$.

Baldis, B., Chebli, G. A. (1969): Estructura profunda del área central de la Precordillera sanjuanina. Actas $4^{a}$ Jornadas Geológicas Argentinas, Buenos Aires, 1, pp. 47-66.

Baldis, B., Peralta, S. H. (1999): Silúrico y Devónico de la Precordillera y Bloque de San Rafael. In R. Caminos (ed.) Geología Argentina. Subsecretaría de Minería de la Nación, Instituto de Geología y Recursos Minerales, Anales 29, pp. 215-238.

Bercowski, F., Figueroa, G. (1987): Flujos piroclásticos en la Formación Albarracín, Terciario, Precordillera de San Juan, Argentina. $10^{\circ}$ Congreso Geológico Argentino, Tucumán, Actas 4, pp. 225-227.

Bercowski, F., Berenstein, L. R., Johnson, N.M. and Naeser, C. W. (1986): Sedimentología, magnetoestratigrafía y edad isotópica del terciario en Loma de las Tapias, Ullum, provincia de San Juan. Primera Reunión Argentina de Sedimentología, Resúmenes Expandidos, La Plata, pp. 169-172.

Bercowski, F., Ruzycky, L., Jordan, T., Zeitler, P., Caballero, M.M. and Pérez, I. (1993): Litofacies y edad Isotópica de la Secuencia La Chilca y su significado Paleogeográfico para el Neógeno de la Precordillera. XII Congreso Geológico Argentino y II Congreso de Exploración de Hidrocarburos, Mendoza, Actas 1, pp. 212-217.

Bordonaro, O. (1999): Cámbrico y Ordovícico de la Precordillera y Bloque de San Rafael. In: R. Caminos (ed.) Geología Argentina Subsecretaría de Minería de la Nación, Instituto de Geología y Recursos Minerales. Anales 29, pp.189-204.

Bordonaro, O. (2003): Evolución paleombiental y paleogeográfica de la cuenca Cámbrica de la Precordillera Argentina. Revista de la Asociación Geológica Argentina 58, 329-346.

Bracaccini, O. (1946-1950): Contribución al conocimiento geológico de la Precordillera Sanjuanino-Mendocina. Boletin de Informaciones Petroleras, 258: 81-105, 260: 259-274, 261: 361-384, 262: 455-473, 263: 22-35, 264: 103-125, 265: 171-192.

Bracaccini, O. (1949): El perfil de Tambolar (provincia de San Juan). Revista de la Asociación Geológica Argentina 4, 165-179.

Bracaccini, O. (1950): Investigaciones tectónicas en la Precordillera Sanjuanina. Boletín de Informaciones Petroleras, Reimpresión 301, 1-36.

Bracco, A., Silva, E., Trozzo, R. and Peralta, S. (2011): Análisis estratigráficos de los depósitos volcaniclásticos de la Sierra de la Dehesa, San Juan, Argentina. XVIII Congreso Geológico Argentino, Neuquen, Actas, pp. 1306-1307.

Cristallini, E.O., Ramos, V.A. (2000): Thick-skinned and thin-skinned thrusting in La Ramada Fold and Thrust belt: crustal evolution of the High Andes of San Juan, Argentina ( $\left.32^{\circ} \mathrm{SL}\right)$. Tectonophysics 317, 205-235. doi:10.1016/s0040-1951(99)00276-0

Cuerda, A. J. (1969): Sobre las graptofaunas del Silúrico de San Juan. Ameghiniana 6, 223-235.

Cuerda, A. J., Furque, G., (1983): Depósitos carboníferos de la Precordillera de San Juan. Parte II. Comarca La Deheza. Revista de la Asociación Geológica Argentina 38, 381-391.

Gardini, M. (1993): Estructura superficial y profunda del valle de Zonda, San Juan. XII Congreso Geológico Argentino y II Congreso de Exploración de Hidrocarburos, Mendoza, Actas 3, 93-99.

González-Menéndez, L. Gallastegui, G., Cuesta, A., N. Heredia and Rubio-Ordóñez A. (2013): Petrogenesis of Early Paleozoic basalts and gabbros in the western Cuyania terrane: Constraints on the tectonic setting of the southwestern Gondwana margin (Sierra del Tigre, Andean Argentine Precordillera). Gondwana Research 24, 359-376. doi:10.1016/j.gr.2012.09.011

Heim, A. (1952): Estudios Tectónicos en la Precordillera de San Juan (Los ríos San Juan, Jachal y Huaco). Revista de la Asociación Ge- 
ológica Argentina 7, 11-70.

Jordan, T.E., Allmendinger, R.W., Damanti, J.F., Drake, R.E. (1993): Chronology of Motion in a Complete Thrust Belt: The Precordillera, 30-31 ${ }^{\circ}$ S, Andes Mountains. Journal of Geology 101, 135-156.

Kay, S.M., Ramos,V.A., Kay, R. (1984): Elementos mayoritarios y trazas de las vulcanitas ordovícicas en la Precordillera Occidental: Basaltos de rift oceánicos tempranos (?) próximos al margen continental. $9^{\circ}$ Congreso Geológico Argentino, Actas 2, pp. 48-65.

Keller, M. (1999): Argentine Precordillera: Sedimentary and plate tectonic history of a Laurentian crustal fragment in South America. The Geological Society of America, Special Paper 341, 1-131. doi:10.1130/0-8137-2341-8.1

Kelly, J. G. (1962): Geología de las Sierras de Moquina y perspectivas petrolíferas, Dpto. de Jáchal, provincia de San Juan. Yacimientos petrolíferos fiscales, Gerencia de Exploración, (inédito), Buenos Aires.

Leveratto, M.A. (1968): Geología de la zona al oeste de Ullún-Zonda, borde oriental de la Precordillera de San Juan, eruptividad subvolcánica y estructura. Revista de la Asociación Geológica Argentina 23, 129-157.

Leveratto, M.A. (1976): Edad de los intrusivos cenozoicos en la Precordillera de San Juan y su implicancia estratigráfica. Revista de la Asociación Geológica Argentina 23, 129-157.

Milana, J. P. (1991): Sedimentología y magnetoestratigrafía de formaciones cenozoicas en el área de Mogna y su inserción en el marco tectosedimentario de la Precordillera oriental. Tesis de Doctorado, Universidad Nacional de San Juan, (inédito), San Juan.

Milana, J. P., Bercowski, F., Jordan, T. (2003): Paleoambientes y magnetoestratigrafía del Neógeno de la Sierra de Mogna, y su relación con la Cuenca de Antepais Andina. Revista de la Asociación Geológica Argentina 58, 447-473.

Ortiz, A., Zambrano, J. J: (1981): La provincia geológica Precordillera oriental. $8^{\circ}$ Congreso Geológico Argentino, Actas 3, pp. 59-74.

Ramos, V. A. (1988): The tectonics of the Central Andes: $30^{\circ}$ to $33^{\circ} \mathrm{S}$ latitude. In: S. Clark and D. Burchfield (eds.) Processes in Continental Lithospheric Deformation. Geological Society of America, Special Paper 218, 31-54. doi:10.1130/SPE218-p31
Ramos, V. A. (1995): Field guide to the geology of Precordillera folded and thrust belt (Central Andes). Andean Thrust Tectonics Symposium, Commission on Tectonics (I.U.G.S.) - I.C.L., San Juan, Argentina, 1-64.

Ramos, V. A. (1999): Los depósitos sinorogénicos terciarios de la Región Andina. In: R. Caminos (ed.) Geología Argentina. Subsecretaría de Minería de la Nación, Instituto de Geología y Recursos Minerales, Anales 29, pp. 663-682.

Ramos, V. A., (2004): Cuyania, an exotic block to Gondwana: Review of a historical success and the present problems. Gondwana Research 7, 1009-1026. doi:10.1016/s1342-937x(05)71081-9

Ramos, V. A., Vujovich, G. I. (2000): Hoja Geológica 3169-IV (San Juan). Programa Nacional de Cartas Geológicas de la República Argentina 1: 250.000. Servicio Geológico Minero Argentino, Boletin 243. Buenos Aires.

Riba, O., (1976): Syntectonic unconformities of the Alto Cardener, Spanish Pyrenees: A genetic interpretation. Sedimentary Geology 15, 213-233. doi:10.1016/0037-0738(76)90017-8.

Vergés, J., Ramos, E., Seward, D., Busquets, P., Colombo, F. (2001): Miocene sedimentary and tectonic evolution of the Andean Precordillera at $31^{\circ} \mathrm{S}$, Argentina. Journal of South American Earth Sciences 14, 735-750. doi:10.1016/S0895-9811(01)00070-0

Vergés, J., Ramos, V. A., Meigs, A., Cristallini, E., Bettini, F. H., Cortés, J. M. (2007): Crustal wedging triggering recent deformation in the Andean thrust front between at $31^{\circ} \mathrm{S}$ and $33^{\circ} \mathrm{S}$ : Sierras Pampeanas-Precordillera interaction. Journal of Geophysical Research 112 , B03S15. doi:10.1029/2006jb004287

von Gosen, W. (1992): Structural evolution of the Argentine Precordillera: the Rio San Juan section. Journal of Structural Geology 14, 643667. doi:10.1016/0191-8141(92)90124-f

Zapata, T. R., Allmendinger, R. W. (1996a): Thrust-Front Zone of the Precordillera, Argentina: A Thick-Skinned Triangle Zone. AAPG Bulletin 80(3), 359-381.

Zapata, T. R., Allmendinger, R. W. (1996b): Growth stratal records of instantaneous and progressive limb rotation in the Precordillera thrust belt and Bermejo basin, Argentina. Tectonics 15, 1065-1083. doi: $10.1029 / 96 \mathrm{TC} 00431$ 